Neutron Induced Reactions 


\section{SLOVAK ACADEMY OF SCIENCES}

Institute of Physics, Electro-Physical Research Centre of the Slovak Academy of Sciences

Reviewer:

Ing. Š. Luby, DrSc. 


\title{
NEUTRON INDUCED REACTIONS
}

\section{Proceedings of the 4th International Symposium Smolenice, Czechoslovakia, June 1985}

\author{
Edited by
}

\section{J. Krištiak and E. Běták}

Institute of Physics, Electro-Physical Research Centre, Slovak Academy of Sciences, Bratislava, Czechoslovakia

\section{Reidel Publishing Company}

A MEMBER OF THE KLUWER ACADEMIC PUBLISHERS GROUP 


\section{Library of Congress Cataloging-in-Publication Data}

Neutron Induced Reactions.

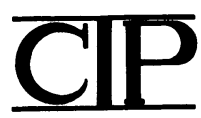

1. Nuclear reactions - Congresses. 2. Neutrons - Congresses. I. Krištiak, J. (Jozef), 1942 - . II. Běták, E. III. International Symposium on Neutron Induced Reactions (4th: 1985: Smolenice, Czechoslovakia). IV. Title.

QC793.9.N47 $1986 \quad 539.7 ' 5 \quad 86-3227$

ISBN-13:978-94-010-8561-8 e-ISBN-13:978-94-009-4636-1

DOI: $10.1007 / 978-94-009-4636-1$

Distributors for the U.S.A. and Canada

Kluwer Academic Publishers,

101 Philip Drive, Assinippi Park, Norwell, MA 02061, U.S.A.

Distributors for Albania, Bulgaria, People's Republic of China,

Cuba, Czechoslovakia, German Democratic Republic, Hungary,

Korean People's Democratic Republic, Mongolia, Poland, Rumania,

U.S.S.R., Vietnam, and Yugoslavia

VEDA, Publishing House of the Slovak Academy of Sciences,

Bratislava, Czechoslovakia.

Distributors of all remaining countries

Kluwer Academic Publishers Group,

P.O. Box 322, 3300 AH Dordrecht, Holland.

First edition published in 1986 by VEDA, Bratislava,

in co-edition with D. Reidel Publishing Company, Dordrecht, Holland.

All rights reserved.

(C) 1986 by VEDA, Publishing House of the Slovak Academy of Sciences

Softcover reprint of the hardcover 1st edition 1986

No part of the material protected by this copyright notice may be reproduced or utilized in any form or by any means, electronic or mechanical, including photocopying, recording or by any information storage and retrieval system, without written permission from the copyright owner. 
CONTENTS

Preface •. • . . . . . . . . . . . . •

REACTIONS

Invited talks

P. E. Hodgson: Pre-equilibrium processes in nuclear reactions . . . . . . . . . . . . . .

A. Iwamoto, K. Harada and K. Sato: Nucleons clusteri-

T. Tamura, T. Udagawa and M. Benhamou: Multistep direct reaction analyses of continuum reactions . .

H. A. Weidenmuller: Novel approach to the statistical

Contributions

T. J. Al-Janabi, A. B. Kadhim, S. J. Hasan, K. M. Mahmood and $A$. J. Al-Azawi: Inelastic scattering cross-section of $160,162,164$ Dy using the time-offlight technique (poster)............

R. Antalik: Microscopic description of direct contribution to neutron inelastic scattering . . . .

E. Běták: Walkers, slaves, or toth? (poster) . . .

T. Elfruth, D. Hermsdorf, H. Kalka, D. Seeliger, K. Seidel and S. Unholzer: The neutron emission from lead bombarded with $14 \mathrm{MeV}$ neutrons (poster).

M. Florek, I. Szarka, J. Oravec, K. Holý, E. Mišianiková, H. Helfer, U. Jahn and Yu. P. Popov: The 
$(n, \alpha)$ reactions on the ${ }^{95} \mathrm{Mo}$ and ${ }^{143} \mathrm{Nd}$ isotopes with $3 \mathrm{MeV}$ neutrons (poster) . . . . . . . .

H. Kalka, D. Hermsdorf and D. Seeliger: Exciton model and multistep compound reactions . . . . . . .

G. N. Lovtsikova, O. A. Salnikov, S. P. Simakov and A. M. Trufanov: Nuclear level density determined from the analysis of spectra of $\left(n, n^{-}\right)$and $(p, n)$ reactions (poster) ...............

B. Milek and R. Reif: Neutron emission in large amplitude collective motions (poster) ......

P. Obložinsky: Particle-hole level densities in the approximation of homogeneous spectrum of singleparticle levels ............ . . .

P. Obložinský: Particle-hole state densities for statistical multistep compound reactions (poster) •.

S. Sudár, R. WOlfle and S. M. Qaim: Deriving excitation function of ${ }^{27} \mathrm{Al}[(n, t)+(n, n t)]$ reaction from measurement performed in diverse neutron fields (poster) .................

Du Xiang Wan and Zhang Ben Ai: On mechanisms of reac-

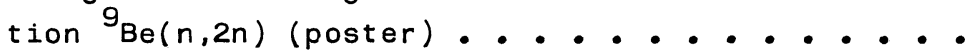

Tian-Yan Zhang: Consideration of the $(n, d)$ and $(p, d)$ scattering and break-up reactions through singular equations (poster) ................

STRUCTURE AND INTERACTIONS

Invited talks

0. Dumitrescu: Alpha clusterization . . . . . .

J. Rapaport: Isovector effective interactions. An empirical approach . . . . . . . . . . . .

V. G. Soloviev: Description of neutron and radiative strength functions in the quasiparticle-phonon nuclear model . . . . . . . . . . . .

Contributions

G. Rohr: A method to determine the pairing energy for excited nuclei . . . . . . . . . . . . 
D. Ryckbosch, E. Van Camp, R. Van de Vyver,

P. Berkvens, E. Kerkhove, P. Van Otten and

H. Ferdinande: Isospin mixing during the decay of

the giant dipole resonance (poster) ........

A. I. Vdovin and $\mathrm{Ch}$. Stoyanov: Strength functions of high-lying single-neutron states ........

188

RESONANCES AND GAMMA EMISSION

Invited talks

R. E. Chrien: Neutron resonance averaging with filtered beams............... 200

F. Cvelbar and A. Likar: Experimental study of fast neutron capture . . . . . . . . . . . 221

M. A. Lone: Photon strength functions . . . . . 238

S. Raman and J.E. Lynn: Applications and misapplications of the channel-capture formalism of direct neutron capture . . . . . . . . . . . .

Z. Szefliński: Verification of the Brink hypothesis giant dipole resonances built on excited states..

Contributions

R. Antalik: Gamma-ray competition in continuum (poster) . . . . . . . . . . . . . .

E. Běták and J. Dobeš: Neutron-gamma coincident calculations within the pre-equilibrium model . . . .

S. Hlaváč, P. Obložinský and J. Pivarč: The

${ }^{52} \mathrm{Cr}(n, \times n j)$ reactions at $14.6 \mathrm{MeV}$ studied by coincident in-beam techniques (poster) ........

V. K. Ignatovich, A. Meister, S. Mittag, W. Pilz,

D. Seeliger and K. Seidel: Temperature shift of neutron resonances ...............

A. Meister, S. Mittag, L. B. Pikelner, W. Pilz, D. Seeliger, K. Seidel: Chemically induced shifts of uranium neutron resonances . . . . . . . .

J. Rondio, B. Marianski, K. Czerski, A. Korman and L. Zemło: GDR excitation in ${ }^{58} \mathrm{Ni}(n, p){ }^{58} \mathrm{Co}_{0}$ reaction at $17.3 \mathrm{MeV}$ neutron energy (poster) . . . . . 


\section{FISSION}

\section{Invited talks}

H. Marten and D. Seeliger: Measurement and theoretical calculation of the ${ }^{252} \mathrm{Cf}$ spontaneous-fission neutron spectrum . . . . . . . . . . . .

C. Wagemans: $(n, p),(n, \alpha)$ and neutron induced ternary fission reactions ..............

Contributions

A. A. Goverdovsky, B. D. Kuzminov, V. F. Mitrofanov and A. I. Sergachev: Peculiarities of mean kinetic energy dependence of fragments at nuclei fission by neutrons (poster) ...............

H. Marten, D. Richter, D. Seeliger, W. D. Fromm and D. Neubert: Differential study of ${ }^{252} \mathrm{Cf}(\mathrm{sf})$ neutron emission (poster) . . . . . . . . . . .

P. Schillebeeckx, C. Wagemans, A. J. Deruytter and $R$. Barthélémy: Shell effects in the spontaneous fission and the thermal neutron induced fission of several Pu-isotopes . . . . . . . . . . .

Yu. A. Selitsky, V. B. Funstein and V. A. Yakovlev: Cross-sections of ${ }^{236} \mathrm{~Np}$ isomers' fission by thermal neutrons (poster) . . . . . . . . . . .

Ch. Straede, C. Budtz-Jørgensen and H.-H. Knitter: ${ }^{235} U(n, f)$ fragment mass, kinetic energy and angular

INSTRUMENTATION

Invited țalk

0 . A. Wasson: Progress in the detection of low-energy neutrons . . . . . . . . . . . . . . .

Contributions

A. V. Andriashin, B. V. Devkin, A. A. Lychagin, J. V. Minko, A. N. Mironov, V. S. Nesterenko, T. Sztaricskai, G. Pety and L. Vasváry: Time-of-flight 
spectrometer for the measurement of gamma correlated neutron spectra (poster) .........

P. Eckstein, F. Gleisberg, H. Helfer, R. Krause, U. Jahn, E. Paffrath, D. Schmidt, D. Seeliger, A. I. Glotov and V. A. Romanov: Design of a multipurpose intense neutron generator (poster) . . .

M. Georgieva, D. Elenkov, D. Lefterov and G. Toumbev:

Two-target DSAM with fast reactor neutrons in $\mathrm{Si}_{\mathrm{i}}$ (poster) .....................

J. Pivarč, S. Hlaváč, P. Obložinský, V. Matoušek, R. Lórencz, I. Turzo and L. Dostál: Recent developments in the multipurpose intense $14 \mathrm{MeV}$ neutron source at Bratislava (poster) . . . . . . . 


\section{PREFACE}

The Fourth International Symposium on Neutron Induced Reactions was held at the Smolenice Castle, Czechoslovakia, June 17-21, 1985.

It was sponsored by the European Physical Society and the Union of Slovak Mathematicians and Physicists.

The primary aim of the Symposium was to provide space for reports on developments in the field of nuclear reaction theory, studies of decay of unbound nuclear states excited by simple projectile as well as on methodical and instrumental progress in the low energy nuclear physics.

Ample time was deliberately reserved for discussions and the exchange of ideas among the participants.

Two committees have been involved in organizing the Symposium: the International Advisory Committee has been advising on topics and selection of speakers and the Organizing Committee has taken a burden of usual daily work.

The members of both committees are listed below.

The International Advisory Committee:

H. H. Barschall (USA), H. Feshbach (USA), J. Formánek (Czechoslovakia), I. M. Frank (USSR), E. Gadioli (Italy), M. K. Mehta (India), S. Raman (USA), I. Ribanský (Czechoslovakia), D. Seeliger (GDR), C. Wagemans (Belgium), H. A. Weidemuller (FRG),

Z. Wilhelmi (Poland).

The Organizing Committee:

R. Antalík, E. Běták, Š. Gmuca, S. Hlaváč, J. Krištiak (Secretary), S. Luby, P. Obložinský, J. Pivarč, I. Ribanský, J. Šácha (all from the Institute of Physics, Electro-Physical Research 
Centre of the Slovak Academy of Sciences, Bratislava), J. Dobeš (Institute of Nuclear Physics, Řež near Prague), I. Wilhelm (Charles University, Prague).

The Symposium was organized in seven sessions with 13 invited talks and 11 orally presented short contributed papers. Three poster sessions have been arranged so that all other contributed papers could be presented as posters. The chairmen of the sessions, M. K. Mehta, R. E. Chrien, I. Ribanský, H. A. Weidenmuller, C. Wagemans, V. G. Soloviev, J. Rapaport, were excellent in their guidance of the discussions which were, in many cases, very lively.

These Proceedings contain texts of almost all papers presented at the Symposium. Unfortunately, it came that all manuscripts had to be edited and retyped. They were carefully compared with originals, however, such a procedure is not guaranteed to be an error-free one and we ask an excuse for occurred errors. We also take opportunity to redraw some of the figures.

In this book, the papers have been grouped by subject in somewhat different order from that in the conference programme.

The major credit for the success of the Symposium goes to all the speakers for their stimulating and excellent talks and to attendance for their active participations in the discussions and social events.

Anyone (including us) who thinks that planning and running a conference is entertainment is relieved of this fancy by actually running it. Therefore, we want to thank the members of the International Advisory Committee for their support and help. We should like to acknowledge the work of the members of the Organizing Committee, who cared for transportations, technical aids and poster sessions.

From early stages of the Symposium its secretaries Miss E. Kubincová and Mrs. D. Strapcová dedicated a sizeable fraction of their time to organization. We highly appreciate them for their competence and charm.

Once more, many thanks to all those who made everything run smoothly. 